\title{
Penentuan Tes Kepribadian Calon Mahasiswa Berdasarkan Sidik Jari Menggunakan Minutie dan Support Vector Machine
}

\author{
Lukman Hakim ${ }^{1 *}$, Hendro $2 * *$ \\ * Teknik Informatika, Universitas Bunda Mulia \\ ** Teknik Informatika, Universitas Bunda Mulia \\ lhakim2710@gmail.com ${ }^{1}$
}

\section{Article Info \\ Article history: \\ Received 2020-02-06 \\ Revised 2020-03-21 \\ Accepted 2020-04-17}

Keyword:

Minutie,

Support Vector Machine,

Fingerprint,

Personality.

\begin{abstract}
Every human being is given its own uniqueness by an almighty god, one of which is a part of the body organs such as the fingerprint pattern of the hand, the fingerprint pattern of each human being determines personality, this can be known from many previous studies, which use fingerprints or someone's detection by the police to capture the perpetrators with the biometry approach in the form of footprint fingerprint records attached to other objects. Determination of a person's personality can be known through fingerprints, and also can adjust prospective students in choosing the study program correctly. Fingerprint student personality identification application provides convenience in determining the choice of prospective students of the study program. The minutie method and the Support Vector Machine algorithm are used in clustering personalities according to training data in the application. The minutie test on the fingerprint pattern shows $100 \%$ compatibility, with a precision input image source. SVM algorithm in testing reached $80,9 \%$ in grouping personality types accordingly.
\end{abstract}

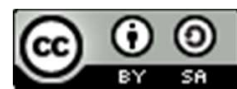

This is an open access article under the CC-BY-SA license.

\section{Pendahuluan}

Kepribadian adalah sifat hakiki yang tercermin pada sikap seseorang atau suatu bangsa yang membedakannya dari orang atau bangsa lain. Kepribadian seseorang dapat diidentifikasi dengan pola sidik jari berdasarkan teori dermatoglyphics [1]. Dermatoglyphics merupakan bidang ilmu yang mempelajari pola sidik jari, telapak tangan, pola sidik jari setiap manusia berbeda, pola dapat mengidentifikasikan pada kepribadian seseorang [2]. Berdasarkan data tingkat DO (Drop Out) mahasiswa masih banyak terjadi pada setiap perguruan tinggi dengan kasus salah jurusan dan sulitnya mempelajari matakuliah tersebut, berdasarkan hal tersebut perlu adanya penelitian psikologi, dengan menggunakan deteksi sidik jari, hal ini mendorong penulis untuk melakukan penelitian dengan menggunakan membaca pola sidik jari dan algoritma berbasis komputer.

Kepribadian bukan sekedar style, preferensi, atau ciri-ciri temperamen seseorang. Kepribadian bisa menjadi peluru ampuh atau menjadi penghambat kesuksesan karir seseorang bilamana tidak disadari oleh individu, Prof Robert Hogan menggambarkan kepribadian sesorang pada pekerjaan dalam 3 bagian yang saling terkait. Pertama adalah the Bright Side, kepribadian yang menunjang karirnya, kedua adalah the Dark Side yang menggambarkan reaksi yang cenderung muncul ketika seseorang mengalami kesulitan atau konflik dan bagian yang ketiga lebih menggambarkan nilai-nilai yang dipentingkan individu dalam berkarir yang dapat memotivasi dia untuk semakin berprestasi [3]. Kepribadian yang secara khusus dilakukan pihak perusahaan untuk melihat lebih jauh kecocokan calon karyawan mereka terhadap perusahaan dan juga lowongan pekerjaan yang tersedia [4]. Tes kepribadian untuk calon mahasiswa sangat penting diketahui untuk keberlanjutan mahasiswa tersebut sesuai dengan karir yang dicapai. Selain itu kepribadian juga termasuk dalam menentukan kecocokan dalam pemilihan program studi yang akan diambil. Kepribadian dapat diidentifikasi melalui sidik jari dengan keterkaitan setiap jari pada struktur otak, sidik jari ibu jari terhubung ke bagian lobus pre-frontal, telunjuk terhubung kebagian lobus frontal, jari tengah terhubung ke 
bagian lobus parietal, jari manis terhubung ke bagian lobus temporal dan jari kelingking terhubung ke bagian lobus occipital [1].

Aplikasi identifikasi sidik jari dibuat dengan tujuan untuk (1) mengetahui lebih dini inteligen berkaitan kepribadian[1] calon mahasiswa, (2) memberikan kemudahan tim marketing atau prodi dalam mengarahkan calon mahasiswa dalam menentukan program studi, dan (3) memberikan kemudahan SAC (Student Advisor Center) dalam memberikan masukan konsultasi dengan mahasiswa dan menunjang perguruan tinggi dalam pencapian prestasi.

Berdasarkan permasalahan diatas dibutuhkan aplikasi identifikasi sidik jari berupa citra sidik jari berasal dari setiap calon mahasiswa atau mahasiswa dibanding dengan dataset menggunakan metode minutie dan untuk klaster setiap kepribadian menggunakan SVM. Aplikasi identifikasi memberikan manfaat untuk mengetahui kepribadian mahasiswa atau calon mahasiswa berdasarkan pola sidik jari, penelitian ini mengetahui sejauhmana tingkat akurasi metode minutie dan algoritma support vector machine dalam melakukan identifikasi pola sidik jari.

\section{LANDASAN TEORI}

\section{A. Kepribadian dan Sidik Jari}

Kepribadian berasal dari kata personality yang berasal dari kata persona (bahasa Latin) yang berarti kedok atau topeng, yaitu tutup muka yang sering dipakai oleh pemain-pemain panggung, yang maksudnya untuk menggambarkan perilaku, watak atau pribadi seseorang [5]. Ada berbagai macam pendekatan teori kepribadian, namun yang paling banyak digunakan dan diterapkan adalah teori tipe kepribadian yang diperkenalkan oleh Hippocrates yang membagi tipe kepribadian menjadi empat, yaitu tipe koleris (choleric), sanguinis (sanguine), melankolis (melancholic), dan phlegmatic (phlegmatic). Florence littaure dalam beberapa seri buku kepribadiannya juga mengupas lebih dalam mengenai kepribadian berdasarkan klasifikasi empat tipe kepribadian tersebut dan sangat mudah untuk diaplikasikan dalam dunia pengembangan sumber daya manusia [6]. Sidik jari itu unik, yang berarti sesuatu yang membedakan dari orang lain. Sidik jari memiliki empat pola dasar dermatoglif yang diformulasikan. Polanya adalah whorl atau Swirl, Arch, Loop, dan Delta. Selain itu, beberapa pola lainnya adalah variasi dari empat kombinasi pola ini [7].

1) Whorl

Whorl adalah bentuk spiral, bulls-eye, atau double loopfingerprint. Whorl memiliki poin yang menonjol dan kontras dan bisa dilihat dengan mudah [7].

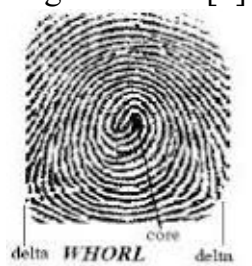

Gambar 1. Pola Sidik Jari Whor

\section{2) Arch}

Pola sidik jari arch merupakan bentuk pokok sidik jari yang semua garis-garisnya datang dari satu sisi lukisan dengan bergelombang naik ditengah-tengah dan tidak memiliki delta.

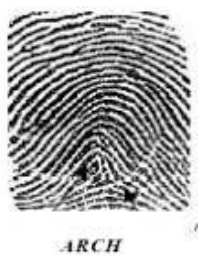

3) Loop

Pola sidik jari loop merupakan suatu bentuk sidik jari dimana satu garis atau lebih datang dari satu sisi lukisan yang mempunyai sebuah delta, sebuah core.

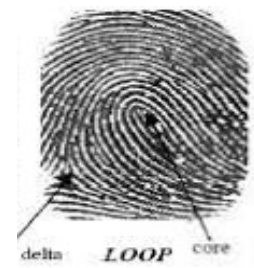

Gambar 3. Pola Sidik Jari Loop

4) Delta

Delta fingerprint sebenarnya adalah titik / garis yang ditemukan pada garis tengah garis putusputus. Delta adalah titik fokus yang terletak di depan pusat pemisahan jalur utama.

\section{B. Pengolahan Citra Digital}

Pengolahan citra sidik jari menggunakan minutie untuk proses verifikasi sidik jari[8]. Terbagi menjadi beberapa tahapan sebagai berikut.

\section{1) Cropping}

Cropping pada pengolahan citra berarti memotong satu bagian dari citra sehingga diperoleh citra yang diharapkan. Ukuran pemotongan citra tersebut berubah sesuai dengan ukuran citra yang diambil. Cropping dilakukan pada koordinat $(x, y)$ sampai pada koordinat $(m, n)[8]$.

\section{2) Thresholding}

Thresholding adalah konversi dari citra hitam-putih menjadi citra biner dilakukan dengan operasi pengambangan (thresholding).

$$
f_{B(i, j)}= \begin{cases}1 & \\ 0 & f_{g(i, j) \leq T}\end{cases}
$$

\section{3) Thinning}

Thinning berguna untuk mengurangi thresholded citra output yang dihasilkan dari edge detector, menjadi garis dengan ukuran ketebalan satu piksel saja

\section{4) Resizing}

Operasi pengubahan ukuran atau resizing pada citra digital adalah operasi memperbesar maupun memperkecil ukuran 
citra. Teknik yang digunakan dalam operasi ini adalah teknik interpolasi.

\section{Metode Minutie}

Minutiae merupakan pola-pola garis yang berkumpul menjadi satu menjadi pola sidik jari manusia [9]. Minutiae adalah karakteristik dari pola pada suatu percabangan dari pola (ridge bifurcation) atau suatu pemberhentian pola sidik jari (ridge ending) [7]. Minutiae memiliki jenis, dan arahnya masing-masing, dalam satu sidik jari dapat terbentuk dari ratusan minutiae sebagai karakteristik suatu individu. Jenisjenis minutiae yang ada pada sidik jari yaitu seperti dots (titik), island (pulau) bentuknya seperti dots tetapi lebih panjang, bifurcation yang bentuknya awalnya terdiri dari dua baris yang lalu bergabung menjadi satu garis, ridge termination yang bentuknya garis yang terputus, lake (danau) yang bentuknya pada suatu garis di tengahnya terdapat perpisahan garis menjadi dua tetapi garis kembali lagi seperti semula yang berbentuk seperti danau pada tengah garis, crossover yang berbentuk dua garis yang tersambung oleh satu garis diantara dua kedua garis tersebut, dan banyak lagi jenis atau bentuk minutiae yang lainnya [9].

\section{Algoritma Support Vector Machine (SVM)}

SVM adalah suatu teknik yang baru (1995) untuk melakukan prediksi, baik dalam kasus klasifikasi maupun regresi yang sangat popular pada saat ini. SVM berada dalam satu kelas dengan ANN dalam hal fungsi dan kondisi permasalahan yang biasa diselesaikan.keduanya masuk dalam kelas supervised learning. Baik para ilmuwan ataupun praktisi telah banyak menerapkan teknik ini dalam menyelesaikan masalah-masalah nyata dalam kehidupan sehari-hari. Baik dalam masalah gene exception analysis, financial, cuaca hingga pada bidang kedokteran. Terbukti dalam banyak implementasi, SVM member hasil yang lebih baik dari ANN, terutama dalam solusi yang dicapai. ANN menemukan solusi berupa local optimal sedangkan SVM menemukan solusi yang global optimal [10].

\section{METODE PENELITIAN}

Penelitian ini harus melakukan pengujian atau uji coba data citra sidik jari, datau dataset yang terkumpul, dan melakukan pengujian algoritma. Tahapan penelitian sidik jari meliputi beberapa tahapan diantaranya adalah mengumpulkan data citra pola sidik jari dari 10 pola jari tangan. Dataset yang terkumpul, disimpan dalam basisdata, yang dapat digunakan pada saat melakukan identifikasi citra sidik jari. Tahap selanjutnya merancangan aplikasi identifikasi sidik jari dengan menggunakan algoritma SVM. Kemudian tahap membuat coding aplikasi identifikasi sidik jari dengan mengimplementasikan metode minutie dan SVM. Tahap terakhir melakukan pengujian metode dan algoritma SVM. Teknik analisis data merupakan suatu langkah yang paling menentukan dari suatu penelitian, karena analisis data berfungsi untuk menyimpulkan hasil penelitian.
Tahapan menentukan pola sidik jari dari dataset berupa citra gambar, sebagai berikut.

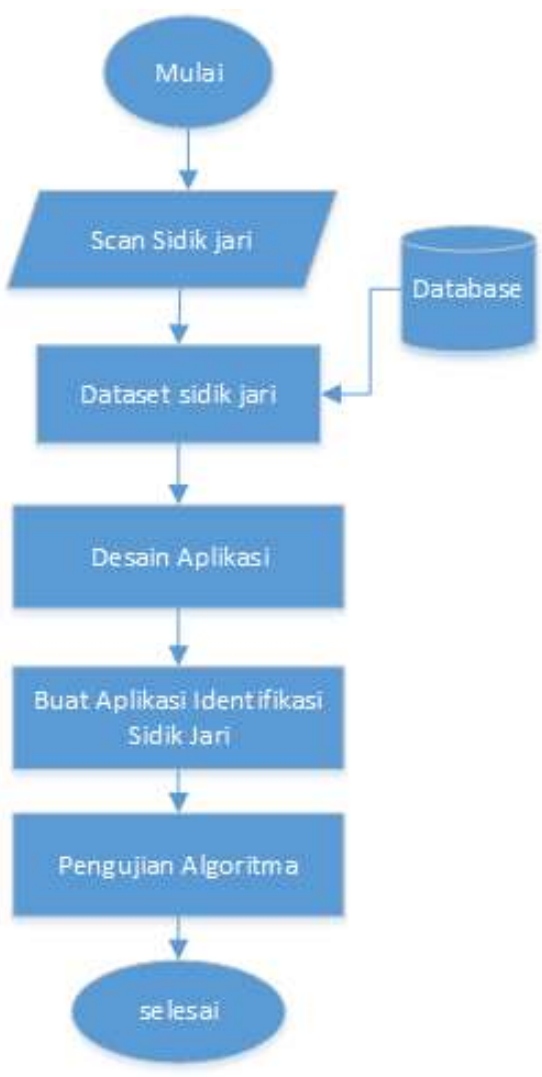

Gambar 3. Tahapan Penelitian

Tahapan analisis data meliputi 5 tahapan, yaitu: (1) mengumpulkan data hasil wawancara dan mengumpulkan dataset pola sidik jari, (2) merancangan aplikasi berdasarkan kebutuhan pengguna, (3) membuat aplikasi identifikasi sidik jari, (4) melakukan pengujian algoritma untuk mengetahui tingkat akurasi dan ketepatan penentuan tipe kepribadian (5) membuat laporan penelitian.

\section{HASIL DAN PEMBAHASAN}

Berikut merupakan hasil dari perancangan aplikasi identifikasi sidik jari.

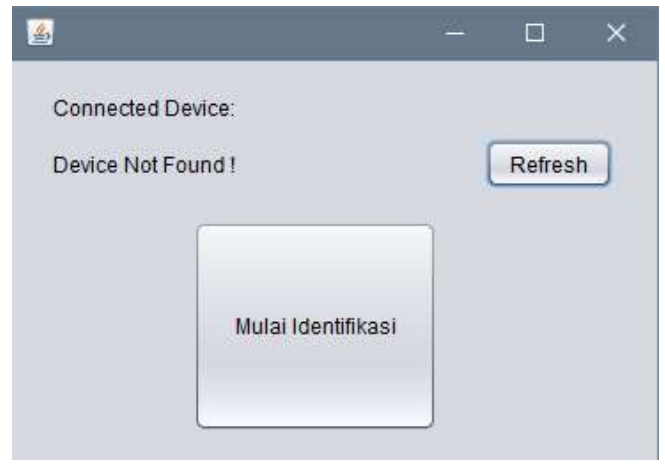

Gambar 4. Aplikasi Identifikasi Sidik Jari 
Gambar 4 merupakan tampilan aplikasi identifikasi sidik jari, aplikasi harus terkoneksi dengan device finger scan, setelah itu tekan tombol refresh untuk aplikasi membaca alat input yang terintegrasi. Aplikasi dibuat sederhana apabila sudah terkoneksi pengguna dapat langsung menempelkan sidik jarinya ke alat finger scan. Tampilan hasil pindai sidik jari dari alat finger scan, sebelum dilakukan proses identifikasi pola sidik jari berdasarkan data training yang sudah ada. Tabel 1. Merupakan pola sidik jari yang pindai oleh aplikasi sebagai berikut:

TABEL I.

POLA SIDIK JARI YANG DIPINDAI

\begin{tabular}{|c|c|}
\hline Gambar Pola & Tipe Pola \\
\hline & Right Loop \\
\hline & \\
\hline & \\
\hline & Arch \\
\hline & \\
\hline
\end{tabular}

Pada tabel 1 merupakan contoh pengenalan pola sidik jari yang dimana setiap pola sidik jari memiliki informasi yang berbeda berdasarkan setiap sidik jari, apabila calon mahasiswa tersebut memiliki pola sidik jarinya tipe right loop pada tangan kanan, aplikasi memberikan informasi sesuai dengan kepribadian berdasarkan pola tersebut.

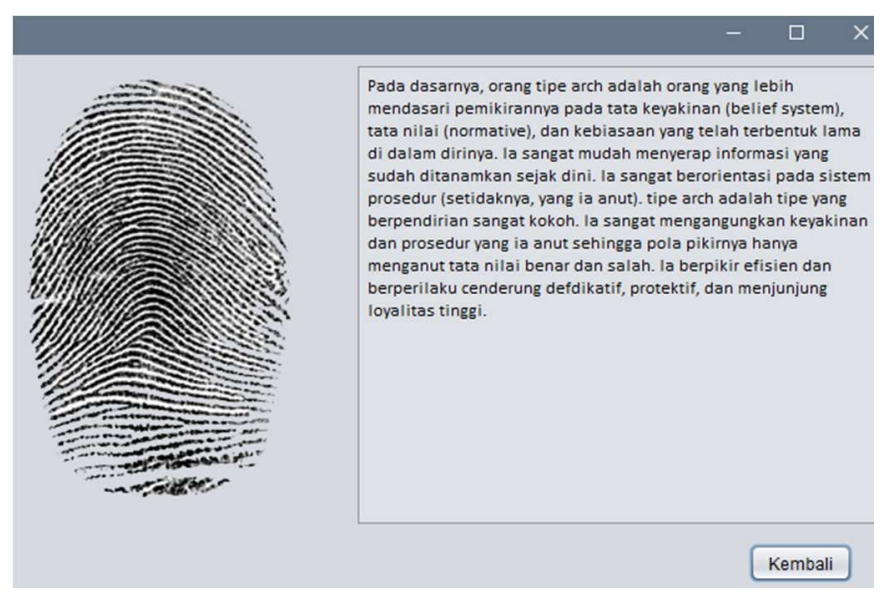

Gambar 5.Tampilan Hasil Klaster Kepribadian
Gambar 5 merupakan hasil dari pindai pada sidik jari, yang ditampilkan beserta informasi berdasarkan pola sidik jari tersebut. Hasil pindai sidik jari yang sebelumnya telah ditranning, dari pola-pola tersebut dikenali dan ditampilkan seperti gambar tersebut.

Tahapan ekstraksi minutiae merupakan langkah awal sebelum masuk pada tahapan penggunaan algoritma Support Vector Machine, ektrasi minutie ada beberapa tahapan diantanya adalah array gambar di proses menjadi array biner, dimana yang menjadi nilai tengah untuk pengubahan nilai citra adalah 128. Setelah diubah menjadi citra array biner, gambar masuk dalam proses thining. Setelah citra selesai masuk dalam proses pre-processing yakni di jadikan array biner dan di proses thining, barulah masuk kedalam proses mencari minutiae yakni ridge ending dan bifurcation dari citra sidik jari.

Pada proses ini, array citra sidik jari di kelompokan menjadi 3 x 3 untuk mempermudah menemukan ridge ending dan bifurcation. Diberi ketentuan jika terdapat jumlah dari array $3 \times 3$ adalah 2, maka disebut sebagai ridge ending dan jika jumlahnya adalah 4 maka dinyatakan sebagai bifurcation. Untuk aplikasi ini menggunakan bahasa pemrograman phyton, dengan menggunakan beberapa library seperti skimage, skimage.morphology sedangkan untuk pemogramannya menggunakan java. Berikut adalah pseudecode algoritma SVM pada script berikut.

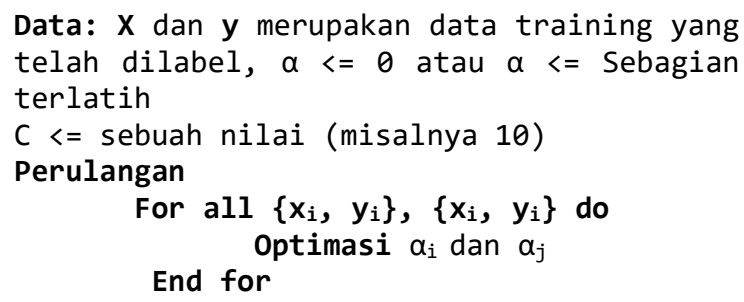

Untuk pengujian sebanyak 9 sampel citra sidik jari, berdasarkan hasil uji pembacaan pola oleh aplikasi $100 \%$ pada metode minutie hasil dikenali. Dimana pola sidik dari yang diujikan type pola whorl 3 citra, Right Loop 3 citra dan Arch 3 citra. Belum semua sidik jari yang diujikan dari setiap polanya. Pengujian dilakukan berulang untuk mengetahui sejauhmana aplikasi mengenal pola sidik jari.

TABEL II.

Pengujian Algoritma Minutie

\begin{tabular}{|c|c|l|c|}
\hline $\begin{array}{c}\text { Pola Sidik } \\
\text { Jari }\end{array}$ & $\begin{array}{c}\text { Type } \\
\text { Kepribadian }\end{array}$ & $\begin{array}{c}\text { Keterangan } \\
\text { Kepribadian }\end{array}$ & $\begin{array}{c}\text { Hasil } \\
\text { Dikenali }\end{array}$ \\
\hline Right Loop & phlegmatic & $\begin{array}{l}\text { Orang yang } \\
\text { memiliki ide, } \\
\text { mengingat } \\
\text { gambar-gambar, } \\
\text { mudah terbawa } \\
\text { emosi }\end{array}$ & $100 \%$ \\
\hline Right Loop & phlegmatic & $\begin{array}{l}\text { Orang yang } \\
\text { memiliki ide, } \\
\text { mengingat }\end{array}$ & $100 \%$ \\
\hline
\end{tabular}




\begin{tabular}{|c|c|c|c|}
\hline & & $\begin{array}{l}\text { gambar-gambar, } \\
\text { mudah terbawa } \\
\text { emosi }\end{array}$ & \\
\hline Right Loop & phlegmatic & $\begin{array}{l}\text { Orang yang } \\
\text { memiliki ide, } \\
\text { mengingat } \\
\text { gambar-gambar, } \\
\text { mudah terbawa } \\
\text { emosi }\end{array}$ & $100 \%$ \\
\hline Arch & Koleris & $\begin{array}{l}\text { Orang yang lebih } \\
\text { mendasari } \\
\text { pemikiran pada } \\
\text { tata keyakinan. }\end{array}$ & $100 \%$ \\
\hline Arch & Koleris & $\begin{array}{l}\text { Orang yang lebih } \\
\text { mendasari } \\
\text { pemikiran pada } \\
\text { tata keyakinan. }\end{array}$ & $100 \%$ \\
\hline Arch & Koleris & $\begin{array}{l}\text { Orang yang lebih } \\
\text { mendasari } \\
\text { pemikiran pada } \\
\text { tata keyakinan. }\end{array}$ & $100 \%$ \\
\hline whorl & Sanguinis & $\begin{array}{l}\text { Orang yang } \\
\text { perasa, orang yang } \\
\text { selalu ingin dipuja- } \\
\text { puja }\end{array}$ & $100 \%$ \\
\hline whorl & Sanguinis & $\begin{array}{l}\text { Orang yang } \\
\text { perasa, orang yang } \\
\text { selalu ingin dipuja- } \\
\text { puja }\end{array}$ & $100 \%$ \\
\hline whorl & Sanguinis & $\begin{array}{l}\text { Orang yang } \\
\text { perasa, orang yang } \\
\text { selalu ingin dipuja- } \\
\text { puja }\end{array}$ & $100 \%$ \\
\hline
\end{tabular}

TABEL III.

HASIL KERJA KLASIFIKASI SIDIK JARI PADA SVM

\begin{tabular}{|c|c|c|c|c|c|c|c|c|c|}
\hline & $s j 1$ & $s j 2$ & $s j 3$ & $s j 4$ & $s j 5$ & $s j 6$ & $s j 7$ & $s j 8$ & $s j 9$ \\
\hline sj1 & 1,00 & 0,00 & 0,00 & 0,00 & 0,00 & 0,00 & 0,00 & 0,00 & 0,00 \\
\hline sj2 & 0,00 & 1,00 & 0,00 & 0,00 & 0,00 & 0,00 & 0,00 & 0,00 & 0,00 \\
\hline sj3 & 0,00 & 0,00 & 1,00 & 0,00 & 0,00 & 0,00 & 0,00 & 0,00 & 0,00 \\
\hline sj4 & 0,00 & 0,00 & 0,00 & 1,00 & 0,00 & 0,00 & 0,00 & 0,00 & 0,00 \\
\hline sj5 & 0,00 & 0,00 & 0,00 & 0,00 & 1,00 & 0,00 & 0,00 & 0,00 & 0,00 \\
\hline sj6 & 0,00 & 0,00 & 0,00 & 0,00 & 0,00 & 1,00 & 0,00 & 0,00 & 0,00 \\
\hline sj7 & 0,00 & 0,00 & 0,00 & 0,00 & 0,00 & 0,00 & 1,00 & 0,00 & 0,00 \\
\hline sj8 & 0,00 & 0,00 & 0,00 & 0,00 & 0,02 & 0,00 & 0,00 & 0,98 & 0,00 \\
\hline sj9 & 0,00 & 0,00 & 0,00 & 0,00 & 0,00 & 0,00 & 0,00 & 0,00 & 1,00 \\
\hline
\end{tabular}

Pada tabel 3 dilihat hasil pengujian klasifikasi sidik jari dengan SVM, hasil pengujian 1 dapat dikenali (100\%), pengujian 2 dapat dikenali (100\%), pengujian 3 dapat dikenali (100\%), pengujian 4 dapat dikenali (100\%), pengujian 5 dapat dikenali (100\%), pengujian 6 dapat dikenali (100), pengujian 8 dapat mengenali (98\%), pengujian 9 dapat mengenali $(100 \%)$. Nilai rata-rata true detection $80.9 \%$ dan false detection $19.1 \%$.

\section{KESIMPULAN}

Berdasarkan hasil pengujian aplikasi identifikasi sidik jari penerapan algoritma minutie dapat mengenali pola dan tipe kepribadian, adanya informasi calon mahasiswa atau mahasiswa berdasarkan tipe kepribadian memudahkan dalam menentukan program studi pilih, untuk algoritma SVM (Support Vector Machine) dapat melakukan klasterisasi mencapai sebesar $80,9 \%$ dan metode minutie dapat mengenali pola $100 \%$. Aplikasi belum sepenuh dapat berjalan sesuai dengan harapan dengan melakukan klaster pada setiap pola seluruh sidik jari perlu ditambahkan data training untuk memudahkan pengenalan pola.

\section{DAFTAR PUSTAKa}

[1] I. G. Sujana, E. Putra, I. K. G. D. Putra, and I. P. A. Bayupati, "Pengenalan Kepribadian Seseorang Berdasarkan Sidik Jari Dengan Metode Fuzzy Learning Vector Quantization Dan Fuzzy Backpropagation," Maj. Ilm. Tek. Elektro, vol. 13, no. 2, 2014.

[2] S. Saparudin and E. Rasywir, "Pengenalan potensi anak melalui sidik jari Menggunakan algoritma voting feature intervals 5 (vfi5)," J. Res. Comput. Sci. Appl., vol. 1, no. 1, pp. 25-30, 2012.

[3] Eileen Rachman \& Emilia Jakob, "No Title," Kepribadian Kunci sukses, 2015.

[4] Fitriana Monica Sari, "No Title," Biar Lolos, Kenali Bentuk Tes Psikologi ini, Liputan 6, 2019.

[5] J. Informatika, L. Hakim, U. B. Mulia, and U. B. Mulia, "Penilaian Kinerja Dosen Tetap Menggunakan K-Mean,” vol. 13, no. April, pp. 87-94, 2019.

[6] S. Shabri, "Hubungan Tipe Kepribadian Dengan Motivasi Belajar Pada Mahasiswa Kurikulum Berbasis Kompetensi Fakultas Keperawatan Universitas Syiah Kuala," Idea Nurs. J., vol. 7, no. 2, pp. 1-12, 2016.

[7] A. P. Nasution, A. B. Osmond, and R. E. Saputra, "Deteksi Kepribadian Anak Dengan Pengolahan Citra Sidik Jari Menggunakan Metode Minutiae Detection Of Children ' S Personality With Fingerprint Image," vol. 5, no. 3, pp. 6102-6109, 2018.

[8] E. P. P. Sandri Titik Wulandari, Ernawati, "aplikasi biometrika pengenalan citra sidik jari dengan metode minutiae dan artificial neural network backpropagation," J. Rekursif, vol. 5, no. 1, pp. 107-120, 2017.

[9] M. R. Syahziar, K. M. Lhaksamana, and S. Al Faraby, "Klasifikasi Sidik Jari Menggunakan Metode Minutiae," e-Proceeding Eng. vol. 5, no. 1, pp. 1803-1810, 2018.

[10] Lukman, "Penerapan Algoritma Support Vector Machine ( SVM ) Dalam Pemilihan Beasiswa: Studi Kasus SMK Yapimda," Fakt. Exacta, vol. 9, no. 1, pp. 49-57, 2016. 